\title{
ANALISIS DAMPAK ADIKSI INTERNET PADA MEDIA SOSIAL TWITTER DI INDONESIA DENGAN PENDEKATAN TEORI KOMUNIKASI
}

\author{
Nadya Berliana Putri, Nada Arina Romli \\ Program Studi Ilmu Komunikasi, Universitas Negeri Jakarta \\ Jln. Pemuda No.18, RT.11/RW.14, Rawamangun, Kecamatan Pulo Gadung, \\ Kota Jakarta Timur, Daerah Khusus Ibukota Jakarta 13220 \\ Nomor HP: 082123539406, 082119703275 \\ e-mail: nadyaberliana2406@gmail.com,nadaarina@unj.ac.id
}

Naskah diterima tanggal 26 Juni 2020 direvisi tanggal 24 Maret 2021 disetujui tanggal

1 April 2021

\begin{abstract}
Abstrak
Twitter merupakan salah satu platform media sosial terkemuka di seluruh dunia. Di Indonesia sendiri, penggunaannya sangat luas mulai dari update status, hiburan sampai berbisnis. Tak heran, berbagai kalangan sangat senang menggunakan media sosial ini. Namun, terdapat dampak dari penggunaan yang terus menerus. Maka dari itu, penulisan artikel ilmiah ini bertujuan untuk menganalisis dampak adiksi internet pada media sosial Twitter di Indonesia dengan pendekatan teori komunikasi. Teori yang digunakan dalam penelitian ini adalah Teori Komunikasi Media Baru oleh Daniel Harries dan Teori Komunikasi Interpersonal oleh Young Yun Kim dan William Gudykunst. Metode yang digunakan pada penelitian ini adalah dengan pendekatan kualitatif dimana teknik pengumpulan data menggunakan kajian pustaka yang memfokuskan pada data sekunder. Hasil penelitian ini menunjukkan bahwa Twitter memanfaatkan proses pembelajaran berbasis bakat alami kita yaitu pemicu, perilaku, dan penghargaan. Kita memiliki ide atau memikirkan sesuatu yang lucu (pemicu), tweet (perilaku), dan menerima likes dan retweet (hadiah). Proses belajar ini menyebabkan aliran dopamin di pusat-pusat otak. Semakin banyak kita melakukan ini, semakin perilaku ini semakin diperkuat bahkan karena kuatnya kebanyakan orang memilih untuk tidak tidur (atau susah tidur) karena euforia yang dirasakan.
\end{abstract}

Kata-kata kunci: Adiksi internet; perilaku; media sosial; teori komunikasi; twitter.

\begin{abstract}
Twitter is one of the leading social media platforms throughout the world. In Indonesia, its use is very wide ranging from status updates, entertainment, to business. Not surprisingly, various groups are very happy to use social media. However, there is an impact of continuous use. Therefore, the writing of this article aims to analyze the impact of internet addiction on Twitter's social media in Indonesia with a communication theory approach. Theories used in this research are New Media Communication Theory by Daniel Harries and Interpersonal Communication Theory by Young Yun Kim and William Gudykunst. The method used in this study is a qualitative approach where data collection techniques use literature review that focuses on secondary data. The results of this study indicate that Twitter makes use of our natural talent-based learning process, namely triggers, behaviors, and rewards. We have ideas or think of something funny (triggers), tweet (behavior), and receive likes and retweets (gifts). This learning process causes the flow of dopamine in the centers of the brain. The more we do this, the more amplified this behavior is, even because most people choose not to sleep (or have trouble sleeping) because of the euphoria they feel.
\end{abstract}

Keywords: Internet addiction; behavior; social media; communication theory; twitter.

Pendahuluan

www.journal.uniga.ac.id
Perkembangan teknologi telah meningkat pesat dalam beberapa dekade 
terakhir, terutama di bidang teknologi digital, termasuk jaringan internet. Revolusi digital, dengan pertumbuhan pesat perangkat elektroniknya, telah mengubah cara kita berkomunikasi, mendidik, dan menghibur diri kita sendiri, serta bagaimana kita berperilaku sebagai individu dalam masyarakat. Di era ini, remaja dan dewasa muda telah terpapar dengan teknologi digital sejak awal kehidupan mereka. Oleh karena itu, anakanak dan remaja sangat terpengaruh oleh teknologi digital ini. Mereka disebut generasi digital, milenial, atau Y. Generasi ini lebih rentan terhadap kecanduan internet karena perubahan budaya modern di mana orang tua lebih sibuk dan kurang memiliki kendali atas anak-anak mereka, harapan akademik dan pekerjaan yang lebih tinggi, dan paparan terhadap perkembangan teknologi yang luar biasa yang memenuhi kebutuhan mereka dan membantu mereka keluar dari masalah. Karena teknologi telah menjadi bagian integral dari kehidupan sehari-hari, perbedaan antara penggunaan internet yang berlebihan dan fungsional menjadi kabur (Young, 2017).

Dalam beberapa tahun terakhir, perubahan signifikan telah terjadi di seluruh dunia sehubungan dengan ekspansi kuantitatif dan kualitatif dari internet, jejaring sosial dan jumlah orang yang menggunakannya. Jejaring sosial meliputi situs web dan aplikasi yang memungkinkan pengguna untuk berbagi konten, ide, pendapat, kepercayaan, perasaan, dan pengalaman pribadi, sosial, dan pendidikan. Mereka juga memungkinkan komunikasi antara berbagai pengguna di tingkat global. Instagram, Telegram, Facebook, Twitter, Skype, dan WhatsApp adalah di antara jejaring sosial virtual yang paling populer dan umum digunakan (Turner \& Lefevre, 2017). Tahun 2018, jumlah pengguna internet di dunia adalah sekitar 4,021 miliar dan juga 3,196 miliar orang menggunakan jaringan sosial secara teratur di seluruh dunia (Azizi et al., 2019).

Twitter, yang dapat dikategorikan sebagai bentuk spesifik dari aktivitas media sosial, microblogging didirikan pada 2006 dan merupakan salah satu platform media sosial terkemuka (lainnya termasuk Facebook, Instagram, dan Youtube) di seluruh dunia. Statistik terbaru yang dirilis oleh Twitter menunjukkan bahwa jaringan menerima sekitar 1 miliar kunjungan bulanan unik dan menampung sekitar 313 juta pengguna aktif, dengan $82 \%$ adalah pengguna seluler aktif. Menurut sebuah penelitian terbaru oleh Pew Research Center, Twitter adalah platform media sosial kelima yang paling populer di kalangan orang Amerika (Alhabash \& Ma, 2017).

Penggunaan internet yang meluas memberikan remaja keuntungan dengan memfasilitasi akses ke informasi, komunikasi dengan teman, jaringan di media sosial, dan hiburan. Namun demikian, dengan semua keunggulan ini muncul patologi baru. Ada risiko yang muncul dari penggunaan internet yang berlebihan, terutama pada remaja. Paparan dini terhadap teknologi dan penggunaannya yang berlebihan terkait dengan masalah perilaku di antara anakanak dan remaja. Remaja berada dalam tahap perkembangan yang ditandai oleh dorongan untuk menemukan sesuatu yang baru yang disebut pencarian baru, ditandai dengan berani mengambil risiko dan 
kepekaan teman sebaya. Mereka juga berada dalam periode pengembangan fungsi eksekutif, seperti pengaturan sendiri (ITU, 2017).

Fenomena internet ini dapat mengganggu perkembangan mental mereka saat mereka mencari identitas mereka sendiri, serta pembentukan citra diri. Penggunaan internet yang berlebihan bisa berkembang menjadi kecanduan internet. Sindrom mengenai penggunaan media interaktif kompulsif disebut penggunaan media interaktif bermasalah. Dalam sindrom ini, ada empat presentasi yang menonjol yakni permainan, media sosial, pornografi, dan pencarian informasi, dan itu termasuk pencarian online yang tidak terkendali dari setiap informasi tekstual atau visual, termasuk menonton video atau serial televisi. Pola perilaku yang berlebihan dari penggunaan internet memiliki banyak kesamaan mendasar dengan kecanduan zat (Young, 2017).

Kecanduan jejaring sosial mengacu pada kepedulian mental terhadap penggunaan jejaring sosial dan alokasi waktu untuk jejaring-jejaring ini sedemikian rupa sehingga mempengaruhi aktivitas sosial individu lainnya seperti aktivitas pekerjaan dan profesional, hubungan interpersonal, dan kesehatan yang menyebabkan gangguan. hidup mereka. Jejaring sosial memiliki dampak negatif pada kesehatan fisik dan psikologis dan menyebabkan gangguan perilaku, depresi, kecemasan dan mania (Wang et al., 2018). Dalam hal ini, hasil penelitian pada siswa Jerman menunjukkan hubungan positif antara kecanduan facebook, dengan karakter narsisme, depresi, kecemasan dan stres (Brailovskaia \& Margraf, 2017).
Seseorang menggunakan jejaring sosial untuk imbalan seperti melarikan diri dari kenyataan dan hiburan. Berdasarkan teori penjelasan biomedis, keberadaan beberapa kromosom atau hormon, atau kurangnya bahan kimia tertentu yang mengatur aktivitas otak, efektif dalam kecanduan. Menurut teori penjelasan kognitif, kecanduan jejaring sosial disebabkan oleh kognisi yang salah, dan orang-orang cenderung menggunakan jejaring sosial untuk melarikan diri dari masalah internal dan eksternal. Secara umum, kecanduan jejaring sosial diklasifikasikan sebagai bentuk kecanduan hubungan dunia maya (Azizi et al., 2019). Setelah melalui penjabaran fenomena pada latar belakang di atas, penulis mampu menarik judul penelitian yakni "Analisis Dampak Adiksi Internet pada Media Sosial Twitter di Indonesia dengan Pendekatan Teori Komunikasi”.

Kecanduan biasanya dikaitkan dengan perilaku kecanduan dan keterlibatan rangsangan yang kompulsif, seperti bahan kimia psikoaktif (misalnya, alkohol dan obat-obatan), meskipun konsekuensi berbahaya. Namun demikian, kecanduan perilaku terkait dengan konsumsi non-zat, seperti kecanduan digital, baru-baru ini menjadi topik yang sangat menarik (Dogan et al., 2019). Sampai saat ini, satu-satunya gangguan kejiwaan yang telah diakui secara formal adalah perjudian patologis dan gangguan permainan internet (Brailovskaia \& Margraf, 2017). Karena itu, ada kebutuhan mendesak untuk penelitian lebih lanjut dalam hal kecanduan perilaku. Karena media sosial telah menjadi platform penting untuk komunikasi online, beberapa penelitian telah menyelidiki efek perilaku pada penggunaan yang berlebihan. Meskipun beberapa peneliti telah membahas 
kecanduan digital dan internet umum (Stavropoulos et al., 2017) dan efek psikologisnya pada kesepian, kecemasan, dan depresi, peneliti lain telah memfokuskan pada kecanduan situs jejaring sosial (Young et al., 2017).

Grifith mengemukakan bahwa perilaku adiktif adalah perilaku yang memiliki karakteristik tertentu seperti arti penting, modifikasi suasana hati, toleransi, gejala penarikan, konflik, dan kambuh. Perilaku adiktif mengacu pada kebiasaan berulang yang meningkatkan risiko penyakit atau masalah sosial pada seseorang. Selama dekade terakhir, perilaku adiktif, seperti terlalu sering menggunakan internet atau jejaring sosial, telah menjadi bagian dari kehidupan manusia sehari-hari. Kecanduan jejaring sosial mencakup karakteristik seperti mengabaikan masalah kehidupan yang sebenarnya, mengabaikan diri sendiri, mengubah suasana hati, menyembunyikan perilaku adiktif, dan memiliki masalah mental (Al-Yafi et al., 2018).

Konsep kecanduan internet berakar pada kecanduan perilaku, yang memiliki pola perilaku dan penyebab biologis yang mirip dengan kecanduan zat. Dalam beberapa tahun terakhir, kecanduan perilaku ditentukan menurut kriteria yang sama dengan kecanduan zat: toleransi, penarikan, kegagalan berulang untuk mengurangi atau berhenti, dan gangguan dalam kehidupan sehari-hari. Studi neuroimaging dari kecanduan perilaku juga menunjukkan hubungan antara perubahan dalam struktur otak dan orang-orang dalam fungsi otak yang berkaitan dengan penghargaan, emosi, fungsi dan perhatian eksekutif, pengambilan keputusan, dan kontrol kognitif. Beberapa penelitian telah menunjukkan hubungan antara siklus zat dan kecanduan perilaku (Young, 2017).
Beberapa kecanduan perilaku, termasuk penggunaan internet, permainan video, perjudian, makan, seks, belanja, pornografi, dan olahraga, telah digambarkan sebagai kecanduan oleh beberapa peneliti, tetapi itu tidak diterima secara universal oleh komunitas medis. Meskipun mereka menunjukkan keinginan, peningkatan toleransi, ketidakmampuan untuk berpantang, dan berkurangnya kesadaran akan masalah terkait penggunaan, perilaku ini tidak menampilkan perubahan fisiologis yang konsisten yang terlihat pada penggunaan secara adiktif dari zat-zat seperti narkotika, alkohol, dan tembakau. Kecanduan perilaku diperkenalkan sebagai kategori baru gangguan kejiwaan dalam gangguan zat adiktif dengan perjudian patologis sebagai diagnosis dan gangguan permainan internet sebagai subtipe (Kurniasanti et al., 2019).

Kaplan \& Haenlein (2010) mendefinisikan media sosial sebagai kelompok aplikasi berbasis internet yang dibangun di atas fondasi ideologis dan teknologi Web 2.0, yang memungkinkan pembuatan dan pertukaran konten yang dibuat pengguna. Menurut Bradley, di yayasannya, media sosial adalah seperangkat teknologi dan saluran yang ditargetkan untuk membentuk dan memungkinkan komunitas peserta yang berpotensi besar untuk berkolaborasi secara produktif. Demikian pula, Curtis menyatakan, media sosial adalah situs internet di mana orang berinteraksi secara bebas, berbagi dan mendiskusikan informasi tentang satu sama lain dan kehidupan mereka, menggunakan campuran multimedia dari kata-kata pribadi, gambar, video dan audio. Meskipun para peneliti memiliki definisi yang berbeda dari situs media sosial, semua definisi tersebut mengungkapkan fungsi yang bermakna 
sama: situs media sosial adalah situs berbasis web untuk komunikasi sosial di mana pengguna internet dapat membuat komunitas online untuk berbagi informasi satu sama lain (Dao, 2015).

Jaringan sosial memainkan peran penting dalam lingkungan belajar sebagai saluran komunikasi utama dan sumber dukungan sosial. Ketika penggunaan jaringan sosial dikelola dengan buruk, mereka dapat memiliki konsekuensi negatif di tingkat individu dan sosial. Kecanduan jejaring sosial adalah salah satu konsekuensi yang mungkin dialami banyak pengguna jejaring sosial. Dengan demikian, penggunaan luas jejaring sosial adalah bentuk baru kecanduan ringan (Tang \& Koh, 2017). Ada banyak teori berbeda tentang kecanduan internet dan jejaring sosial. Teori yang paling penting termasuk teori psikologi dinamis, teori kontrol sosial, penjelasan perilaku, penjelasan biomedis, dan penjelasan kognitif. Menurut teori psikologi dinamis, akar dari kecanduan jejaring sosial adalah guncangan psikologis atau defisiensi emosional di masa kecil, sifat kepribadian, dan status psikososial. Menurut teori kontrol sosial, karena kecanduan bervariasi dalam hal usia, jenis kelamin, status ekonomi, dan kebangsaan, jenis kecanduan tertentu lebih mungkin ditemukan dalam kelompok masyarakat tertentu daripada kelompok lain (Masthi et al., 2018).

Informasi jaringan internet China melaporkan bahwa $27,3 \%$ dari 485 juta orang yang menggunakan internet adalah remaja. Situasi serupa juga terjadi di Indonesia. Meskipun pertumbuhan internet lebih lambat daripada di negara-negara berkembang lainnya, proporsi orang yang menggunakan internet meningkat dari $0,9 \%$ pada tahun 2000 menjadi $17,1 \%$ pada tahun 2014. Kementerian Komunikasi dan
Informasi, Republik Indonesia bekerja sama dengan Amerika Serikat Dana Anak Bangsa dan meneliti pola penggunaan internet pada remaja. Hasilnya menunjukkan bahwa sekitar $80 \%$ remaja, terutama di Jakarta, Banten, dan Daerah Istimewa Yogyakarta, menggunakan internet dalam kehidupan sehari-hari mereka. Selain itu, data juga melaporkan bahwa Indonesia memiliki jumlah akun Twitter terbesar kelima di dunia. Prevalensi kecanduan internet pada remaja di Asia cenderung lebih tinggi daripada di AS atau Eropa, dan perbedaan budaya ikut berperan dalam hal ini. Remaja Asia cenderung mengalami kesulitan mengekspresikan diri yang mengarah pada ekspresi diri di dunia cyber (Kurniasanti et al., 2019).

Fitur Twitter memungkinkan pengguna untuk mempublikasikan ide dan pendapat mereka dalam format "pesan aktual" dengan menulis tweet terbatas pada sejumlah karakter tertentu (awalnya 140 tetapi sekarang hingga 280). Selain itu, dengan fitur seperti tagar, sebutan, dan balasan, pengguna dapat membangun jaringan dan berdialog dengan pengguna Twitter lainnya (Malik et al., 2019). Berbagai aspek praktik Twitter telah diteliti di sejumlah domain termasuk pariwisata, olahraga, tata kelola, informasi kesehatan, pemilihan umum, dan aktivisme (Johri et al., 2018). Selain menggunakan Twitter untuk hiburan dan rekreasi, platform ini terutama digunakan untuk interaksi sosial, berbagi informasi, pencarian informasi, dokumentasi diri, dan ekspresi diri (Malik et al., 2018).

Menurut New Media Institute, istilah "media baru" adalah istilah umum yang digunakan untuk mendefinisikan semua yang terkait dengan internet dan interaksi antara teknologi, gambar, dan suara. Bahkan, definisi media baru berubah setiap hari, dan 
akan terus berlanjut. Media baru terus berkembang dan berubah. Lebih lanjut, organisasi berpendapat, media baru dapat ditandai dengan beragamnya penggunaan gambar, kata, dan suara. Jaringan gambar, suara, dan data teks ini berbeda dari format media lama seperti surat kabar cetak karena karakteristik konvensionalnya (Harries, 2002). Menurut International Communication Association, komunikasi interpersonal adalah studi tentang perilaku komunikasi dalam pasangan (berpasangan) dan dampaknya terhadap hubungan pribadi. Biasanya ini melibatkan komunikasi verbal, tatap muka dengan dua orang atau lebih. Menguasai kemampuan berkomunikasi secara bermakna dengan kolega, klien, teman, dan keluarga di berbagai latar dapat mengubah karier dan kehidupan. Komunikasi interpersonal melibatkan percakapan antara setidaknya dua orang, sementara itu komunikasi intrapersonal mengacu pada pemikiran dan ekspresi internal seseorang, terutama yang menentukan solusi untuk masalah. Kita mempraktikkan komunikasi intrapersonal ketika kita sedang tenggelam dalam pikiran atau ketika kita sedang bermeditasi, berdoa, atau membuat jurnal (Kim \& Gudykunst, 1988).

\section{Metode Penelitian}

Langkah selanjutnya yang dilakukan peneliti untuk memperoleh jawaban dari pertanyaan penelitian ini adalah dengan menentukan metode yang akan dilakukan. Desain metode yang digunakan pada penelitian ini adalah desain deskriptif dengan pendekatan kualitatif. Teknik pengumpulan data menggunakan kajian pustaka yang memfokuskan pada data sekunder.

\section{Hasil Penelitian dan Pembahasan}

Twitter memanfaatkan proses pembelajaran berbasis bakat alami kita yaitu pemicu, perilaku, dan penghargaan. Kita memiliki ide atau memikirkan sesuatu yang lucu (pemicu), tweet (perilaku), dan menerima likes dan retweet (hadiah). Proses belajar ini menyebabkan aliran dopamin di pusat-pusat otak. Semakin banyak kita melakukan ini, semakin perilaku ini semakin diperkuat bahkan karena kuatnya kebanyakan orang memilih untuk tidak tidur (atau susah tidur) karena euforia yang dirasakan. Berdasarkan pada proses survival adaptif evolusioner yang membantu kita mengingat di mana makanan berada, otak kita sekarang mempelajari lingkaran kebiasaan baru untuk bertahan hidup. Kita bahkan dapat mengidentifikasi pengaruh kita dengan jumlah tayangan, tweet, dan pengikut yang kita miliki.

Sisi berbahaya dari Twitter datang dalam bentuk yang sama. Kita merasa marah pada tweet seseorang, otak kita berteriak "lakukan sesuatu!" dan kita langsung mengirim tweet penuh kemarahan orang itu. Proses belajar dasar yang sama, namun pahala datang dalam dua bentuk, yaitu pembenaran diri dan pembuktian. Seseorang memberi tahu kita melalui "like" atau "retweet". Jika kita memiliki banyak pengikut yang sering berbagi pandangan khusus kita tentang dunia, dan kita ingin menargetkan orang tertentu, kita dapat mengirimkan tweet jahat dan dengan senang hati menonton sebagai troll, saling memberi makan satu sama lain dalam kegilaan, untuk mengabaikan korban yang dituju menjadi terlupakan. Banyak orang telah diintimidasi dari media sosial dengan cara ini.

Namun, dengan media sosial, ada bagian penting dari lingkaran umpan balik ini yang hilang (atau mudah diabaikan) yaitu umpan balik negatif. Kita belajar terbaik melalui 
umpan balik positif dan negatif. Umpan balik membuat kita tetap pada jalurnya. Saat kita bertatap muka dengan seseorang, kita melihat hasil tindakan kita baik dalam bahasa tubuh dan nada suara. Dan dengan semua umpan balik ini, menjadi sangat jelas apakah kita telah menyakiti seseorang atau tidak. Hal ini penting karena kita akan bertindak berbeda jika kita merasa terlibat secara pribadi dengan melakukan sesuatu di luar sana kepada seseorang yang tidak kita kenal atau jika kita tidak dapat melihat bagaimana tindakan kita telah memengaruhi seseorang.

Mengembangkan praktik-praktik kesadaran, seperti perhatian, dapat juga berperan dalam memperhatikan hasil dari tindakan kita. Kita menempatkan diri pada posisi orang di ujung tweet kita. Ini membantu dengan kurangnya umpan balik yang melekat di Twitter. Hal ini membuka ruang untuk tidak memberi umpan saat-saat ketika kita memiliki keinginan yang tampaknya tidak terkendali untuk menunjukkan keangkuhan akun Twitter kita pada seseorang. Alih-alih merasakan dampak yang menggembirakan dan membenarkan diri sendiri, kita bahkan mungkin bisa memperhatikan bagaimana rasanya menahan diri. Dan bersikap baik tidak berlebihan, sebenarnya terasa cukup baik, atau lebih baik.

\section{Kesimpulan}

Twitter jelas telah membuat dampak besar di dunia digital yang telah menjadi penggunaan viral di kalangan generasi baru terutama orang dewasa dan anak muda. Meskipun Twitter memiliki dampak positifnya, ada juga kekurangannya. Di dunia Twitter, pengguna terbukti bagus dalam bersosialisasi tetapi hanya di dunia virtual, pada kenyataannya mereka kesulitan berkomunikasi dengan orang-orang dan dilabeli sebagai anti-sosial. Dengan pengguna yang adiksi Twitter, beberapa pengguna juga menerima beberapa gejala medis di mana mereka mengalami kesulitan tertidur (insomnia) karena aktif di Twitter dan ingin membuat tweet dalam rangka update.

\section{Daftar Pustaka}

Alhabash, S., \& Ma, M. (2017). A tale of four platforms: Motivations and uses of Facebook, Twitter, Instagram, and Snapchat among college students?. Social Media+ Society, 3(1), 2056305117691544.

Al-Yafi, K., El-Masri, M., \& Tsai, R. (2018). The effects of using social network sites on academic performance: the case of Qatar. Journal of Enterprise Information Management.

Azizi, S. M., Soroush, A., \& Khatony, A. (2019). The relationship between social networking addiction and academic performance in Iranian students of medical sciences: a cross-sectional study. BMC psychology, 7(1), 28.

Brailovskaia, J., \& Margraf, J. (2017). Facebook addiction disorder (FAD) among German students-a longitudinal approach. PLoS One, 12(12).

Dao, D. V. (2015). Social media classification scheme in online teaching and learning activities: A consideration for educators. International journal of education and social science, 2(4), 85-94.

Dogan, H., Norman, H., Alrobai, A., Jiang, N., Nordin, N., \& Adnan, A. (2019). A Web-Based Intervention for Social Media Addiction 
Disorder Management in Higher Education: Quantitative Survey Study. Journal of medical Internet research, 21(10), e14834.

Harries, D. (2002). The new media book. British Film Institute.

International Telecommunication Union. (2017). Broadband Access Technologies, Including IMT, for Developing Countries: Final Report [Question 2/1]. International Telecommunication Union.

Johri, A., Karbasian, H., Malik, A., Handa, R., \& Purohit, H. (2018). How diverse users and activities trigger connective action via social media: Lessons from the twitter hashtag campaign\# ilooklikeanengineer. $\quad a r X i v$ preprint arXiv:1804.09226.

Kaplan, A., \& Haenlein, M. (2010). Users of the world, unite: The challenges and opportunities of social media. Business Horizons, 53 (1), 59-68.

Kim, Y. Y., \& Gudykunst, W. B. (1988). Theories in intercultural communication (Vol. 12). Sage Publications, Inc., 2111 West Hillcrest Dr., Newbury Park, CA 91320; Speech Communication Association, 5105 Backlick Rd., Building E, Annandale, VA 22003. Kurniasanti, K. S., Assandi, P., Ismail, R. I., Nasrun, M. W. S., \& Wiguna, T. (2019). Internet addiction: a new addiction?. Medical Journal of Indonesia, 28(1), 82-91.

Malik, A., Johri, A., Handa, R., Karbasian, H., \& Purohit, H. (2018). How social media supports hashtag activism through multivocality: A case study of\#
ILookLikeanEngineer. First Monday, 23(11).

Malik, A., Li, Y., Karbasian, H., Hamari, J., \& Johri, A. (2019). Live, love, Juul: User and content analysis of Twitter posts about Juul. American journal of health behavior, 43(2), 326-336.

Masthi, N. R., Pruthvi, S., \& Phaneendra, M. S. (2018). A comparative study on social media usage and health status among students studying in pre-university colleges of urban Bengaluru. Indian journal of community medicine: official publication of Indian Association of Preventive \& Social Medicine, 43(3), 180.

Stavropoulos, V., Kuss, D. J., Griffiths, M. D., Wilson, P., \& MottiStefanidi, F. (2017). MMORPG gaming and hostility predict Internet addiction symptoms in adolescents: An empirical multilevel longitudinal study. Addictive behaviors, 64, 294-300.

Tang, C. S. K., \& Koh, Y. Y. W. (2017). Online social networking addiction among college students in Singapore: Comorbidity with behavioral addiction and affective disorder. Asian journal of psychiatry, 25, 175-178.

Turner, P. G., \& Lefevre, C. E. (2017). Instagram use is linked to increased symptoms of orthorexia nervosa. Eating and Weight Disorders-Studies on Anorexia, Bulimia and Obesity, 22(2), 277284.

Wang, P., Wang, X., Wu, Y., Xie, X., Wang, X., Zhao, F., ... \& Lei, L. (2018). Social networking sites 
Jurnal Komunikasi Universitas Garut: Hasil Pemikiran dan Penelitian Vol. 7, No. 1, April 2021

Halaman 582-590

addiction and adolescent depression: A moderated mediation model of rumination and self-esteem. Personality and Individual Differences, 127, 162167.

Young, K. S. (2017). Internet addiction in children and adolescents: risk factors, assessment, and treatment. Springer Publishing Company.

Young, N. L., Kuss, D. J., Griffiths, M. D., \& Howard, C. J. (2017). Passive Facebook use, Facebook addiction, and associations with escapism: An experimental vignette study. Computers in Human Behavior, 71, 24-31. 